\title{
Antioxidant, antidiarrhoeal and cytotoxic properties of aerial parts of Trichosanthes dioica Roxb.
}

\section{${ }^{1 *}$ Saleha Akter, ${ }^{2}$ Mohammad Zafar Imam, ${ }^{3}$ S. M. Raquibul Hasan, ${ }^{3}$ Md. Mokarram Hossain, ${ }^{3} \mathrm{Md}$. Ehsanul Hoque Mazumder and ${ }^{3} \mathrm{Md}$. Sohel Rana}

\author{
${ }^{1}$ Department of Pharmacy, Primeasia Univeristy, Banani, Dhaka-1213, Bangladesh \\ ${ }^{2}$ Department of Pharmacy, Stamford University Bangladesh, Siddeswari, Dhaka-1217, \\ Bangladesh \\ ${ }^{3}$ Department of Pharmacy, Jahangirnagar University, Savar, Dhaka, Bangladesh
}

\begin{abstract}
The present study was designed to investigate the antioxidant, antidiarrhoeal and cytotoxic properties of the aerial parts of Trichosanthes dioica. The petroleum ether, ethyl acetate, methanol and water extracts were tested for antioxidant activity using nitric oxide scavenging assay, total antioxidant capacity and total flavonoid content determination; castor oil-induced and magnesium sulphate-induced diarrhoea in mice were used to evaluate antidiarrhoeal activity while Brine shrimp lethality bioassay was employed for cytotoxicity test. The extracts exhibited significant radical scavenging capacity against nitric oxide. The order of radical scavenging was ascorbic acid $>$ water extract $>$ ethyl acetate extract $>$ methanol extract $>$ petroleum ether extract. The assay also revealed significant total antioxidant activity and a good amount of flavonoids in the extracts. Results of antidiarrhoeal tests at the doses of 200 and $400 \mathrm{mg} / \mathrm{kg}$ body weight significantly $(p<0.05,0.001)$ reduced the frequency and severity of diarrhoea in both animal models. Methanol extract showed the highest inhibition of defaecation. The extracts also showed moderate cytotoxicity against Brine shrimp. The results suggest that aerial parts of Trichosanthes dioica possess significant antioxidant, antidiarrhoeal and moderate cytotoxic activities.
\end{abstract}

Key Words: Trichosanthes dioica, Antioxidant, NO scavenging, Flavonoids, Antidiarrhoeal, Cytotoxicity.

\section{INTRODUCTION}

Trichosanthes dioica Roxb. (Family: Cucurbitaceae), locally known as 'Patal', is an important summer cucurbit vegetable of Bangladesh. It is climber plant with cordate-oblong leaves, white flowers and oblong green fruits. According to ayurveda the plant is used for bronchitis, biliousness, jaundice, liver affections (enlargement), cough and blood diseases. It is also used as antipyretic, diuretic, cardiotonic and laxative (Kirtikar and Basu, 1996). The leaf juice is rubbed over the chest in liver congestion and over the whole body in intermittent fevers (Nadkarni, 1998). Trichosanthes dioica possesses anti-inflammatory activity (Fulzule et al., 2001); blood sugar, serum cholesterol, high density lipoprotein, phospholipids and triglyceride lowering activity (Chandrasekhar et al., 1988; Sharma and Pant, 1988). The aerial part of the plant is hypoglycaemic (Rai et al., 2008). The fruits and seeds have some prospects in the control of some cancer like conditions and haemagglutinating activities (Sharmila et al., 2007).
It also has strong hepatoprotective effect (Ghaisas et al., 2008). T. dioica plant is very rich in protein. Fruits contain free amino acids and 5-hydroxy tryptamine. Fatty acids from seeds comprise elaeostearic, linoleic, oleic and saturated acids. The various chemical constituents present in $T$. dioica are vitamin A, vitamin C, tannins, saponin, and trichosanthin (Chopra et al., 1956). Studies also revealed the presence of phenolic compounds in the leaves of $T$. dioica (Baitha and Pandey, 2003). Roots contain an amorphous saponin, hentriacontane, a phytosterol, a non-nitrogenous bitter glucosidic principles, small amount of essential oil, little fixed oil and traces of tannins (Ghani, 2003).

Literature review revealed no combined studies performed regarding the antioxidant, antidiarrhoeal and cytotoxic activities of this plant. Our current study is therefore designed to investigate the antioxidant, antidiarrhoeal and cytotoxic activities of Trichosanthes dioica. 


\section{MATERIALS AND METHODS}

Chemicals and drugs: Sodium nitroprusside was obtained from BDH Chemicals Ltd., Poole, England; Griess reagent from Roch-light Ltd., Suffolk, England; Sodium Phosphate $\left(\mathrm{Na}_{3} \mathrm{PO}_{4}\right)$ from Merck, Mumbai, India; Ammonium Molybdate from Merck DGaA, Germany; Quercetin from Sigma Chemicals, USA; Ascorbic acid from SD Fine chem. Ltd., Biosar, India. Loperamide was purchased from local market.

Plant material: The mature fruiting plants of Trichosanthes dioica were collected from Rajshahi district of Bangladesh in July, 2009. The plant was identified by the taxonomist of the Bangladesh National Herbarium, Mirpur, Dhaka where a voucher specimen has been deposited for future reference (Voucher specimen No. 34191).

Extraction: The aerial part (leaves and stem) of Trichosanthes dioica were dried under shade for seven days and then in the oven at $55^{\circ} \mathrm{C}$. The extraction was carried out by Soxhlet apparatus using four different solvent namely petroleum ether, ethyl acetate, methanol and water. The extracts were then dried by rotary evaporator and these crude extracts were used for investigations.

Animals: Swiss albino mice (22-25 g) of both sex obtained from the Animal Research Division of the International Center for Diarrhoeal Disease and Research, Bangladesh (ICDDR,B), were used to perform antidiarrhoeal studies. The animals were maintained at standard room temperature $\left(25.0 \pm 2.0^{\circ} \mathrm{C}\right)$, humidity (55-65\%) and $12 \mathrm{~h}$ light/ $12 \mathrm{~h}$ dark cycle. The animals were fed standard diet (ICDDR, B formulated) and had free access to water ad libitum.

Phytochemical screening: The crude extracts were tested for detection of the presence of phytochemicals such as carbohydrates, alkaloids, glycosides, anthraquinone glycosides, glucosides, tannins, saponins, flavonoids and steroids following standard procedures (Ghani, 2003).

\section{Tests for Antioxidant Activity}

Nitric oxide scavenging capacity: The nitric oxide radical scavenging capacity of the crude extracts was determined according to Alisi and Onyeze (2008). 1.0 $\mathrm{ml}$ of sodium nitroprusside ( $5 \mathrm{mM}$ ) was added to the plant extracts of different concentrations $(4.0 \mathrm{ml})$. The solution was incubated for $2 \mathrm{~h}$ at $30^{\circ} \mathrm{C} .2 \mathrm{ml}$ of the solution was mixed with $1.2 \mathrm{ml}$ of Griess reagent $(1 \%$ Sulfanilamide, $\quad 0.1 \%$ naphthylethylene diamine dihydrochloride in $\left.2 \% \mathrm{H}_{3} \mathrm{PO}_{4}\right)$. Then the absorbance of the solution was measured at $550 \mathrm{~nm}$ using a spectrophotometer (UV-VIS spectrometer, Shimadzu UV PC-1600, Japan) against blank. The percentage inhibition activity was calculated by the equation $\left\{\left(A_{0}\right.\right.$ $\left.\left.-A_{1}\right) / A_{0}\right\} \times 100$, where $A_{0}$ is the absorbance of the control, and $A_{1}$ is the absorbance of the extract or standard. The inhibition curve was prepared and $\mathrm{IC}_{50}$ values of different extracts were calculated.

Determination of Total Antioxidant Capacity: The phosphomolybdenum method is based on the reduction of $\mathrm{Mo}(\mathrm{VI})$ to $\mathrm{Mo}(\mathrm{V})$ by the antioxidant compounds present in the extracts and subsequent formation of a green phosphate/Mo(V) complex at acid $\mathrm{pH}$ (Prieto et al., 1999). Plant extracts or standard of different concentration solution were mixed with $3 \mathrm{ml}$ of reagent solution $(0.6 \mathrm{M}$ sulfuric acid, $28 \mathrm{mM}$ sodium phosphate and $4 \mathrm{mM}$ ammonium molybdate). Then the mixture was incubated at $95^{\circ} \mathrm{C}$ for 90 min to complete the reaction and the absorbance of the solution was measured at $695 \mathrm{~nm}$ against blank after cooling to room temperature. The antioxidant activity is expressed as the number of equivalents of ascorbic acid (AAE).

Determination of flavonoid content: The total flavonoid content of the crude extracts was determined by the method described by Chang et al. (2002). $1 \mathrm{ml}$ of extract solution $(100 \mu \mathrm{g} / \mathrm{ml})$ or quercetin (standard) in different concentrations were mixed with $3 \mathrm{ml}$ methanol, $200 \mu \mathrm{l}(10 \%)$ aluminium chloride solution and $200 \mu \mathrm{l}(1 \mathrm{M})$ potassium acetate solution. Then $5.6 \mathrm{ml}$ of distilled water was added to the mixture and incubated for $30 \mathrm{~min}$ at room temperature. The absorbance of the solution was measured at $415 \mathrm{~nm}$ against blank. The total content of flavonoid compounds in plant extracts were calculated and expressed as $\mathrm{mg}$ of quercetin equivalents (QE) / gm of extract.

\section{Tests for antidiarrhoeal activity}

Castor oil-induced diarrhoea: Antidiarrhoeal activity of the extracts was tested in castor oil-induced diarrhoea in mice according to the method described by Shoba and Thomas (2001). The experimental animals were all screened at first with $0.5 \mathrm{ml}$ of castor oil per mice and those animal showing diarrhoea were selected for the experiment. The animals were divided into ten groups each containing five animals. Group I and II were given 1\% Tween 80 in water (10 $\mathrm{ml} / \mathrm{kg}$, p.o.) and Loperamide (3 $\mathrm{mg} / \mathrm{kg}$, p.o.) respectively. The test groups (Group III-X) received the petroleum ether, ethyl acetate, methanol and water extracts at the doses of 200 and $400 \mathrm{mg} / \mathrm{kg}$ 
(p.o.) body weight respectively. The mice were placed into cages and the floor of the cage was lined with blotting paper. Diarrhoea was induced by oral administration of $0.5 \mathrm{ml}$ castor oil to each mouse, 30 min after the above treatments. During an observation period of $4 \mathrm{~h}$, the total numbers of diarrhoeic faeces excreted by the animals were recorded.

\section{Magnesium sulphate-induced diarrhoea:} Diarrhoea was induced in the experimental mice by oral administration of magnesium sulphate at the dose of $2 \mathrm{gm} / \mathrm{kg}$ to the animals $30 \mathrm{~min}$ after administration of $1 \%$ Tween 80 in water $(10 \mathrm{ml} / \mathrm{kg}$, p.o.) to the control group, Loperamide (3 $\mathrm{mg} / \mathrm{kg}, \mathrm{p} . \mathrm{o}$.) to the positive control group, the petroleum ether, ethyl acetate, methanol and water extracts at the doses of 200 and $400 \mathrm{mg} / \mathrm{kg}$ to the test groups (Doherty, 1981). The observations were made for $4 \mathrm{~h}$ and total numbers of diarrhoeal droppings were recorded.

Cytotoxic activity test: The cytotoxic activity of the crude extracts was investigated using Brine shrimp lethality bioassay (McLaughlin, 1982). Artemia salina Leaches (brine shrimp eggs) was collected and taken in a small tank of water at $37^{\circ} \mathrm{C}$ with constant oxygen supply to allow hatching of the shrimps for two days and to mature as nauplii. Five $\mathrm{ml}$ of seawater was taken in each vial. Specific volume of the test samples were taken and dissolved in specific volume of dimethyl sulfoxide (DMSO) to get stock solutions. Then a series of solutions of varying concentrations were prepared from the stock solution by serial dilution method and was added to the vials. The concentrations of the obtained solutions in the vials were as $1 \mu \mathrm{g} / \mathrm{ml}, 5 \mu \mathrm{g} / \mathrm{ml}, 10 \mu \mathrm{g} / \mathrm{ml}, 20 \mu \mathrm{g} / \mathrm{ml}, 50$ $\mu \mathrm{g} / \mathrm{ml}, 100 \mu \mathrm{g} / \mathrm{ml}, 200 \mu \mathrm{g} / \mathrm{ml}$ and $500 \mu \mathrm{g} / \mathrm{ml}$. Ten nauplii were added by micropipette to each of the vials. After $24 \mathrm{~h}$, the vials were inspected using a magnifying glass and the number of survived nauplii in each vial was counted and the percentage of lethality of the brine shrimp nauplii was calculated for each concentration.

Statistical Analysis: Statistical analysis was carried out using one way analysis of variance (ANOVA) followed by Dunnett's tests using SPSS Statistics 17.0 for windows. The results obtained were compared with the control group. $p$ values $<0.05$ were considered to be statistically significant .

\section{RESULTS AND DISCUSSION}

Phytochemical screening revealed the presence of alkaloids, flavonoids, carbohydrates and tannins in different extracts. The extracts were found to contain good amount of flavonoids. Methanol extract contained $823.88 \mathrm{mg}$ flavonoids /gm of plant extract in quercetin equivalent (QE). Petroleum ether, ethyl acetate and water extract contained 57.55, 288.16 and $315.71 \mathrm{mg}$ flavonoids / gm of plant extract in QE respectively.

The scavenging of nitric oxide radical by the extracts was concentration dependent. The result was comparable to ascorbic acid that was used as reference (Figure 1). The $I C_{50}$ values of ascorbic acid was $4.71 \mu \mathrm{g} / \mathrm{ml}$ while the petroleum ether, methanol, ethyl acetate and water were, $337.58 \mu \mathrm{g} / \mathrm{ml}, 43.06$ $\mu \mathrm{g} / \mathrm{ml}, \quad 34.38 \mu \mathrm{g} / \mathrm{ml}$ and $16.39 \mu \mathrm{g} / \mathrm{ml}$. In total antioxidant capacity test, the extracts showed significant antioxidant activity. The petroleum ether, ethyl acetate, methanol and water extract showed total antioxidant capacity of 515.55, 862.59, 605.92 and128.70 $\mathrm{mg} / \mathrm{gm}$ of plant extract in AAE respectively.

It has been recognized that flavonoids show antioxidant activity and their effects on human health are considerable (Pourmorad et al., 2007). The mechanisms of action of flavonoids are through scavenging or chelating process (Cook and Samman, 1996; Kessler et al., 2003). Flavonoids contain hydroxyls that are responsible for the radical scavenging effect of the extracts (Das and Pereira, 1990). Nitric oxide or reactive nitrogen species, formed during their reaction with oxygen or with superoxides are responsible for altering the structural and functional behaviour of many cellular components. The extracts may have the property to counteract the effect of NO formation and in turn may be of considerable interest in preventing the ill effects of excessive NO generation in the human body. Further, the scavenging activity may also help to arrest the chain of reactions initiated by excess generation of NO that are detrimental to the human health. Nitric oxide is also implicated for inflammation and other pathological conditions (Moncada et al., 1991). 


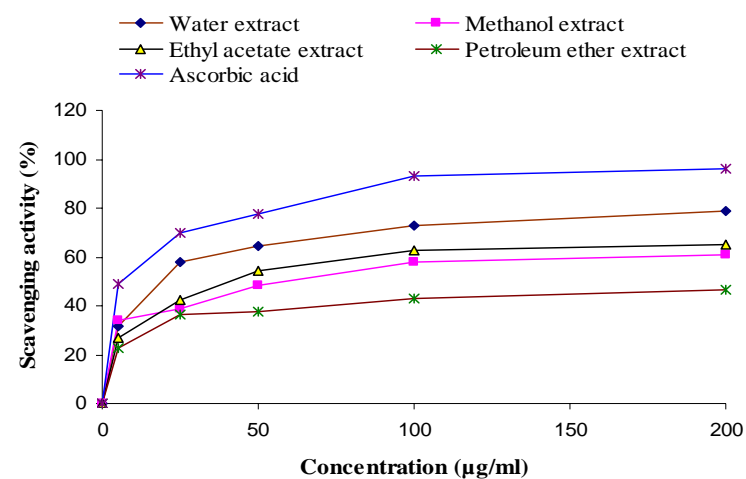

Figure 1: Nitric oxide (NO) radical scavenging activity of the different extracts of the aerial part of
Trichosanthes dioica. Values are presented as mean $\pm \mathrm{SD}$.

In castor oil-induced diarrhoea, all the four extracts of $T$. dioica at doses of $200 \mathrm{mg} / \mathrm{kg}$ and $400 \mathrm{mg} / \mathrm{kg}$ reduced the total number of faeces in a dose dependent manner (Table 1). The inhibition of characteristic diarrhoeal droppings was also recorded at both doses in magnesium sulphate-induced diarrhoea. The extracts were found to reduce the total number of faeces significantly $(p<0.05,0.001)$ when compared to control (Table 2). Methanol extract at $400 \mathrm{mg} / \mathrm{kg}$ dose showed the highest inhibition of diarrhoeal droppings in both model.

Table 1: Effect of different extracts of the aerial parts of Trichosanthes dioica on castor oil-induced diarrhoea in mice.

\begin{tabular}{|c|c|c|c|c|}
\hline Groups & Treatment & Dose (p.o.) & $\begin{array}{c}\text { No. of faecal } \\
\text { droppings in } 4 \mathrm{~h}\end{array}$ & $\begin{array}{c}\text { \% Inhibition of } \\
\text { defaecation }\end{array}$ \\
\hline Group-I & 1\% Tween 80 in water & $0.4 \mathrm{ml} / \mathrm{mouse}$ & $24.8 \pm 2.699$ & - \\
\hline Group-II & Loperamide & $3 \mathrm{mg} / \mathrm{kg}$ & $6.2 \pm 1.396^{\star \star}$ & 75.00 \\
\hline Group-III & \multirow{2}{*}{ Petroleum ether extract } & $200 \mathrm{mg} / \mathrm{kg}$ & $17.2 \pm 1.366$ & 30.65 \\
\hline Group-IV & & $400 \mathrm{mg} / \mathrm{kg}$ & $16.6 \pm 1.648^{*}$ & 33.6 \\
\hline Group-V & \multirow{2}{*}{ Ethyl acetate extract } & $200 \mathrm{mg} / \mathrm{kg}$ & $14.8 \pm 0.975^{\star}$ & 40.32 \\
\hline Group-VI & & $400 \mathrm{mg} / \mathrm{kg}$ & $9.8 \pm 1.966^{\star \star}$ & 60.48 \\
\hline Group-VII & \multirow{2}{*}{ Methanol extract } & $200 \mathrm{mg} / \mathrm{kg}$ & $13.4 \pm 1.794^{*}$ & 45.97 \\
\hline Group-VIII & & $400 \mathrm{mg} / \mathrm{kg}$ & $9.4 \pm 1.432^{\star \star}$ & 62.10 \\
\hline Group-IX & \multirow{2}{*}{ Water extract } & $200 \mathrm{mg} / \mathrm{kg}$ & $15.2 \pm 2.149 *$ & 38.71 \\
\hline Group-X & & $400 \mathrm{mg} / \mathrm{kg}$ & $12.2 \pm 1.987^{\star \star}$ & 50.81 \\
\hline
\end{tabular}

Values are mean \pm SEM, $(\mathrm{n}=5) ;{ }^{\star} p<0.05,{ }^{\star \star} p<0.001$, Dunnett's test as compared to control. 
Table 2: $\quad$ Effect of different extracts of the aerial parts of Trichosanthes dioica on magnesium sulphate-induced diarrhoea in mice.

\begin{tabular}{|l|l|l|c|c|}
\hline \multicolumn{1}{|c|}{ Groups } & \multicolumn{1}{|c|}{ Treatment } & \multicolumn{1}{c|}{ Dose (p.o.) } & $\begin{array}{c}\text { No. of faecal } \\
\text { droppings in 4 } \mathbf{~}\end{array}$ & $\begin{array}{c}\text { \% Inhibition of } \\
\text { defaecation }\end{array}$ \\
\hline Group-I & $1 \%$ Tween 80 in water & $0.4 \mathrm{ml} / \mathrm{mouse}$ & $21.6 \pm 2.113$ & - \\
\hline Group-II & Loperamide & $3 \mathrm{mg} / \mathrm{kg}$ & $6.4 \pm 1.770^{\star \star}$ & 70.37 \\
\hline Group-III & \multirow{2}{*}{ Petroleum ether extract } & $200 \mathrm{mg} / \mathrm{kg}$ & $16.6 \pm 1.839$ & 23.15 \\
\cline { 4 - 5 } & & $400 \mathrm{mg} / \mathrm{kg}$ & $15.4 \pm 1.571$ & 28.70 \\
\hline Group-IV & \multirow{2}{*}{ Ethyl acetate extract } & $200 \mathrm{mg} / \mathrm{kg}$ & $13.0 \pm 1.936^{\star}$ & 39.81 \\
\cline { 3 - 5 } & & $400 \mathrm{mg} / \mathrm{kg}$ & $10.4 \pm 1.211^{\star \star}$ & 51.85 \\
\hline Group-VI & \multirow{2}{*}{ Group-VII } & $200 \mathrm{mg} / \mathrm{kg}$ & $13.2 \pm 1.426^{\star}$ & 38.89 \\
\cline { 3 - 5 } & & $400 \mathrm{mg} / \mathrm{kg}$ & $7.2 \pm 0.975^{\star \star}$ & 66.67 \\
\hline Group-VIII & \multirow{2}{*}{ Water extract } & $200 \mathrm{mg} / \mathrm{kg}$ & $13.8 \pm 1.835^{\star}$ & 36.11 \\
\cline { 3 - 5 } Group-IX & & $400 \mathrm{mg} / \mathrm{kg}$ & $9.8 \pm 1.238^{\star \star}$ & 54.64 \\
\hline Group-X & & &
\end{tabular}

Values are mean \pm SEM, $(\mathrm{n}=5) ;{ }^{*} p<0.05,{ }^{* \star} p<0.001$, Dunnett's test as compared to control.

Induction of diarrhoea by castor oil and magnesium sulphate in the experimental animal is due to their effect on the secretion/absorption process in the biological system. Ricinoleic acid, the active constituents of castor oil has been reported to reduce active $\mathrm{Na}^{+}$and $\mathrm{K}^{+}$absorption and decrease $\mathrm{Na}^{+}, \mathrm{K}^{+}$ ATPase activity in the small intestine and colon (Gaginella, 1975). The antidiarrhoeal activity was evident from the reduction of total number of wet faeces in the test groups in the experiment. Magnesium sulphate has been reported to induce diarrhoea by increasing the volume of intestinal content through prevention of reabsorption of water (Uddin et al., 2005). It has also been demonstrated that it promotes the liberation of cholecystokinin from the duodenal mucosa, which increases the secretion and motility of small intestine and thereby prevents the reabsorption of sodium chloride and water (Galvez et al., 1993 a, b). Ethyl acetate, methanol and water extracts of $T$. dioica showed a significant antidiarrhoeal activity against castor oil-induced and magnesium sulphate-induced diarrhoea in experimental animals. The methanol extract showed almost similar activity as Loperamide, when tested at 200 and $400 \mathrm{mg} / \mathrm{kg}$ doses and statistically significant reduction in the frequency of defecation when compared to control mice. The ethyl acetate, methanol and water extracts were also found to alleviate the diarrhoeic condition. It is possible that the antisecretory and antioxidant properties of different phytoconstituents may contribute to the observed antidiarrhoeal effect. The antidiarrhoeal activity of flavonoids has been ascribed to their ability to inhibit intestinal motility and hydro-electrolytic secretion, which are known to be altered in this intestinal condition (Rao et al., 1997). In addition, flavonoids present antioxidant properties which are presumed to be responsible for the inhibitory effects exerted upon several enzymes including those involved in the arachidonic acid metabolism (Mora et al., 1990; Su et al., 2000).

In Brine shrimp lethality bioassay, all the extracts produced concentration dependent increment in percent mortality of Brine Shrimp nauplii indicating the possible presence of cytotoxic principles in these extracts. The $\mathrm{LC}_{50}$ values of petroleum ether, ethyl acetate and methanol extract were $603.04 \mu \mathrm{g} / \mathrm{ml}$, $434.92 \mu \mathrm{g} / \mathrm{ml}$ and $290 \mu \mathrm{g} / \mathrm{ml}$ respectively. The water extract showed and $\mathrm{LC}_{50}$ value $>1000 \mu \mathrm{g} / \mathrm{ml}$. The cytotoxic activity of the extracts may be correlated with the presence of trichosanthin in the plant. Trichosanthin is a ribosome inactivating protein which shows antitumor, immunosuppressive and HIV-1 inhibitor activity by cleaving the supercoiled doublestranded DNA (Li et al., 1991; Kong et al., 1998).

\section{CONCLUSION}

The results of the present study suggest that the aerial parts of Trichosanthes dioica possess significant antidiarrhoeal, antioxidant and moderate 
cytotoxic properties. Further studies are needed to identify, separate and characterize the bioactive chemical constituents and to find out the possible mechanisms of antioxidant, antidiarrhoeal and cytotoxic activities.

\section{REFERENCES}

Alisi, C.S., Onyeze, G.O. C (2008). Nitric oxide scavenging ability of ethyl acetate fraction of methanolic leaf extracts of Chromolaena odorata(Linn.). African J. Biochem. Res. 2(7): 145-150.

Baitha, N.S., Pandey, V.S (2003). Silica gel chromatographic study of phenolic compounds in some cultivated cucurbits. Himalayan J. Sci. 1(2): 123125.

Chandrasekhar, B., Mukherjee, B., Mukherjee, S.K (1988). Blood sugar lowering effect of Trichosanthes dioica Roxb. in experimental rat models. Int. J. Cru. Drug Res. 26: 102-106.

Chang, C., Yang, M., Wen H., Chern, J. (2002). Estimation of total flavonoid content in propolis by two complementary colorimetric methods. J. Food Drug Anala. 10: 178-182.

Chopra, R.N., Nayar, S.L., Chopra, I.C (1956). Glossary of Indian Medicinal plants. CSIR, New Delhi.

Cook, N.C., Samman, S (1996). Flavonoids- chemistry, metabolism, cardioprotective effects, and dietary sources. Nutri. Biochem. 7: 66- 76.

Das, N.P., Pereira, T.A (1990). Effects of flavonoids on thermal autooxidation of Palm oil: structure- activity relationship. J. American Oil Chem. Soc., 67: 255258.

Doherty, S.S (1981). Inhibition of arachidonic acid release, mechanism by which glucocorticoids inhibit endotoxininduced diarrhoea. British J. Pharmacol. 73: 549-554.

Fulzule, S.V., Satturwar, P.M., Joshi, S.B (2001). Studies on anti-inflammatory activity of a poly herbal formulation- Jatydi Ghrita. Indian Drugs 39(1): 42-44.

Gaginella, T.S., Stewart J.J., Olson W.A., Bass P (1975). Actions of ricinoleic acid and structurally related fatty acid on the gastro-intestinal tract II. Effects on water and electrolyte absorption in vitro. J. Pharmacol. Exp. Ther. 195: 355-361.

Galvez, J., Crespo, M.E., Jimenez, J., Suarez, A., Zarzuelo, A (1993a). Anti-diarrhoeic activity of quercitrin in mice and rats. J. Pharm. Pharmacol. 45: 157-159.

Galvez, J., Zarzuelo, A., Crespo, M.E., Lorente, M.D., Ocete, M.A., Jimenez, J (1993b). Antidiarrhoeic activity of Euphorbia hirta extract and isolation of an active flavonoid constituent. Planta Med. 59: 333-336.

Ghaisas, M.M., Tanwar, M.B., Ninave, P.B., Navghare, V.V., Takawale, A.R., Zope, V.S., Deshpande, A.D
(2008). Hepatoprotective activity of aqueous and ethanolic extract of Trichosanthes dioica Roxb. in ferrous sulphate-induced liver injury. Pharmacologyonline 3: 127-135.

Ghani, A (2003). Medicinal Plants of Bangladesh. 2nd ed. The Asiatic Society of Bangladesh. Dhaka, Bangladesh. 415, 500-505.

Kessler, M., Ubeaud, G. Jung, L (2003). Anti- and prooxidant activity of rutin and quercetin derivatives. J. Pharm. Pharmacol. 55: 131- 142.

Kirtikar, K.R., Basu, B.D (1996). Indian Medicinal Plants.

Kong, M., Ke, Y.B., Zhou, M.Y., Ke, X.Y., Lu, B., Nie, H.L (1998). Study on Trichosanthin induced apoptosis of leukemia K562 cells. Acta Biologiae Experimentalis Sinica 31(3): 233-243.

Li, M.-X., Yeung, H.-W., Pan, L.-P., Chan S.I (1991). Trichosanthin, a potent HIV-1 inhibitor, can cleave supercoiled DNA in vitro. Nucleic Acids Res. 19(22): 6309-6312.

McLaughlin, J. L (1982). Brine shrimp: a convenient general bioassay for active constituents. Planta Med. 45: 31-32.

Moncada, A., Palmer, R.M.J., Higgs, E. A (1991). Nitric oxide: physiology, pathophysiology and pharmacology. Pharmacol. Rev. 43: 109-142.

Mora, A., Paya, M., Rios, J.L., Alcaraz, M.J (1990). Structure activity relationships of polymethoxy flavones and other flavonoids as inhibitors of non-enzymic lipid peroxiation. Biochem. Pharmacol. 36: 317- 322.

Nadkarni, K.M (1998). Indian Medicinal Plants and Drugswith their Medicinal Properties and Uses. Asiatic Publishing House New Delhi. p. 450.

Pourmorad, F., Hosseinimehr, S.J., Shahabimajd, N (2006). Antioxidant activity, phenol and flavonoid contents of some selected Iranian medicinal plants. African J. Biotechnol. 5(11): 1142-1145.

Prieto, P., Pineda, M., Aguilar, M (1999). Spectrophotometric quantitation of antioxidant capacity through the formation of a phosphomolybdenum complex: Specific application to the determination of vitamin E. Analyt. Biochem. 269: 337- 341.

Rai, P.K., Jaiswal, D., Singh, R.K., Gupta, R.K., Watal, G (2008). Glycemic Properties of Trichosanthes dioica Leaves. Pharm. Biol. 46(12): 894 - 899.

Rao, V.S.N., Santos, F.A., Sobreika, T.T., Souza, M.F., Melo, L.L., Silveira, E.R (1997). Investigations on the gastroprotective and antidiarrhoeal properties of ternatin, a tetramethoxyflavone from Egletes viscose. Planta Med. 63: 146-1497.

Sharma, G., Pant, M.C (1988). Preliminary observations on serum biochemical parameters of albino rabbits 
fed on Trichosanthes dioica (Roxb.). Indian J. Med. Res. 87: 398-400.

Sharmila, B.G., Kumar, G., Rajasekhara, P.M (2007). Cholesterol-lowering activity of the aqueous fruit extract of Trichosanthes dioica Roxb. in normal and streptozotocin diabetic rats. J. Clin. Dia. Res. 1(4): 561-569.

Shoba, F.G., Thomas, M (2001). Study of antidiarrhoeal activity of four medicinal plants in castor oil induced diarrhoea. J. Ethnopharmacol. 76: 73-76.
Su, Y.L., Leung, L.K., Bi, Y.R., Huang, Y., Chen, Z.Y (2000). Antioxidant activity of flavonoids isolated from Scutellaria rehderiana. J. Am. Chem. Soc. 77: 807812.

Uddin, S.J., Shilpi, J.A., Alam, S.M.S., Alamgir, M., Rahman, M.T., Sarker, S.D (2005). Antidiarrhoeal activity of the methanol extract of the barks of Xylocarpus moluccensis in castor oil- and magnesiumsulphate-induced diarrhoea models in mice. J. Ethnopharmacol. 101:139-143. 